\title{
Do Canadian Companies Employ Big Bath Accounting When Recording Goodwill Impairment?
}

\author{
Charles E. Jordan ${ }^{1} \&$ Stanley J. Clark ${ }^{2}$ \\ ${ }^{1}$ Department of Accounting, Florida State University-Panama City, Panama City, Florida, USA \\ ${ }^{2}$ Department of Accounting, Middle Tennessee State University, Murfreesboro, Tennessee, USA \\ Correspondence: Charles E. Jordan, Florida State University-Panama City, 8339 High Point Rd., Panama City, FL, \\ 32404, USA. Tel: 1-850-872-0085. E-mail: cejordan@fsu.edu
}

Received: June 17, 2015

Accepted: July 2, 2015

Online Published: August 25, 2015

doi:10.5539/ijef.v7n9p159

URL: http://dx.doi.org/10.5539/ijef.v7n9p159

\begin{abstract}
In the transition year (2002) during which the respective goodwill impairment standards were implemented in the U.S. and Canada, these impairment losses received favorable treatment (i.e., as below-the-line expenses in the U.S. and as adjustments to retained earnings in Canada). Research in this transition year showed that goodwill impairments were recorded opportunistically in both the U.S. and Canada. Subsequent to the transition year, however, accounting principles in all countries require that goodwill impairments be presented in a more punitive fashion, with the write downs appearing as above-the-line operating expenses in the income statement. Research in the U.S. during the post-transition period provides mixed results as some studies indicate goodwill impairments are opportunistically recorded in a manner reflective of big bath behavior while others suggest these write downs convey economic information from management to users about a firm's financial performance. No such studies have been conducted in Canada during the post-transition period. The present research fills this void in the literature by examining recent data on Canadian firms and finds evidence suggesting that goodwill impairments in this country are not being recorded opportunistically to take big baths but instead are being recognized only after multiple years of substandard earnings have occurred, thus indicating managers are recording these impairments to provide relevant information to financial statement users.
\end{abstract}

Keywords: big bath behavior, Canada, goodwill impairment, IAS 36

\section{Introduction}

Walsh, Craig, and Clarke (1991) describe big bath accounting as recording large profit reducing write offs to "wipe the slate clean" in the current year, thus allowing enhanced profitability and rates of return in the future. They note that the big hit would be taken in a year when earnings are already low because "making things just a little bit worse by cleaning out the rubbish does little harm to either reputation or prospects" (Walsh et al., 1991, p. 174). The researchers also indicate that a crucial factor in employing big bath accounting is the opportunity to make it happen.

AbuGhazaleh, Al-Hares, and Roberts (2011) indicate that International Accounting Standard (IAS) 36, Impairment of Assets, provides such an opportunity relative to recording goodwill impairment, which requires numerous discretionary choices by management. For example, when a business acquisition is made, any ensuing goodwill must be arbitrarily allocated to each of the acquiring entity's cash generating units (CGUs) expected to benefit from that business combination. Then, goodwill associated with each CGU must be tested at least annually for impairment by comparing the recoverable amount of the CGU with its carrying value. A CGU's recoverable amount represents the higher of the CGU's fair value less the costs of disposal or its value in use, which is the present value of the cash flows expected from operating the CGU. If the CGU's carrying value exceeds its recoverable amount, an impairment loss exists. This loss is recorded as an operating expense and a reduction of the goodwill associated with the CGU. If the loss exceeds the carrying value of the goodwill, any remaining expense is allocated on a pro rata basis among the other assets in the CGU.

AbuGhazaleh et al. (2011) note that the significant discretion inherent in the goodwill impairment test in IAS 36 allows managers either to convey their private information about the economic performance of an entity or alternatively to report opportunistically in a manner that is less reflective of economic reality (e.g., taking a big 
bath to enhance future profitability or rates of return). Massoud and Raiborn (2003) indicate that similar accounting discretion exists in the U.S. goodwill impairment standard i.e., Statement of Financial Accounting Standard (SFAS) 142. Indeed, research in the U.S. suggests that in the year SFAS 142 was adopted and shortly thereafter, managers opportunistically recorded goodwill impairments (e.g., Jordan \& Clark, 2004; Sevin \& Schroeder, 2005).

Yet, in the year of adopting the goodwill impairment standard (i.e., the transition year), impairment losses received favorable treatment in most countries by being presented as below-the-line items in the income statement. In Canada, the treatment was even more favorable as goodwill impairments bypassed income entirely and instead were recorded as reductions of retained earnings. After the transition year, though, goodwill impairments in all countries using either U.S. GAAP or IFRS have been reported in a more punitive fashion as above-the-line operating expenses in the income statement. Research shows that both the market and managers consider the distinction between reporting impairments above-the-line versus below-the-line to be important, with the consequences of above-the-line presentation perceived as much more severe (Beatty \& Weber, 2006; Bens \& Heltzer, 2004).

Lapointe-Antunes, Cormier, and Magnan (2008) examined the recording of goodwill impairments in Canada in the transition year (2002) and found evidence suggesting the impairments were reported opportunistically. The current study analyzes goodwill impairments in Canada for a post-transition year (2013) to ascertain whether managers in this country continue this tradition or instead have opted to record goodwill impairments that signal relevant economic information about a firm's performance over time. The results suggest the latter, more altruistic reporting of goodwill impairments seems to be occurring.

In section two, we review the literature relative to earnings management accomplished through goodwill impairments and develop the research question for the study. Section three describes the methodology and data collection; this is followed by a discussion of the results in section four. Finally, section five contains our summary and conclusion and identifies the limitations of the study.

\section{Literature Review and Development of Research Question}

SFAS 142 began requiring annual impairment testing of goodwill in the U.S. in 2002. As noted previously, in this transition year, goodwill impairments were reported below-the-line in the earnings statement (i.e., as the cumulative effect of a change in accounting principle). Two studies (Jordan \& Clark, 2004; Sevin \& Schroeder, 2005) tested for big bath earnings management via goodwill impairment in the U.S. in 2002. The former study examined the Fortune 100 companies, while the latter project analyzed a group of randomly selected firms of varying sizes. The results in both studies suggested managers opportunistically recorded goodwill impairments by taking the hit when income was already depressed that year. That is, in 2002 the group of firms recording an impairment reported pre-impairment earnings that were significantly lower than the income for the companies not writing down goodwill. Yet, in the prior year (2001), both groups of firms reported similar earnings levels. This suggested the group of companies recording an impairment in 2002 did so not because of poor economic performance over time, but rather because of the depressed earnings in the current year only, which is a key ingredient of big bath behavior. Sevin and Schroeder's (2005) results indicated small firms displayed a greater propensity than large firms to record goodwill impairments opportunistically.

Jordan, Clark, and Vann (2007) examined goodwill impairments in the U.S. in 2003 and 2004 to ascertain whether the presentation of these losses as above-the-line operating expenses deterred management from the opportunistic reporting behavior noted in the transition year (2002). The magnitude of the goodwill impairments reported in 2003 and 2004 was significantly smaller than the amounts presented in 2002, which suggested managers opportunistically selected 2002 to take large write offs due to the favorable reporting treatment they received in the transition year. Even so, the more harsh presentation of goodwill impairments as operating expenses in 2003 and 2004 apparently did not stop managers from practicing big bath accounting as, similar to the transition year findings of Jordan and Clark (2004) and Sevin and Schroeder (2005), the group of firms recording goodwill impairments in 2003 and 2004 reported significantly lower pre-impairment earnings than the group of non-impairment firms in the year of impairment only. Prior to the impairment year, there was little differential in the earnings levels of the two groups.

Beatty and Weber (2006) examined U.S. firms that were likely candidates for goodwill impairments in the transition year and shortly thereafter to ascertain what factors (other than economic performance) affected managers' decisions to take these write downs. They found that managers considered the distinction between reporting impairment losses above-the-line versus below-the-line to be important. For example, the researchers discovered that when firms' debt covenants specifically included the effects of an accounting change (i.e., a 
below-the-line item), companies with greater net worth covenant slack were more likely to record an impairment in the transition year than were firms with more binding covenants, who instead preferred to delay the expense recognition. In addition, they found evidence suggesting that the closer a company was to falling below the delisting threshold for its respective stock exchange, the less likely a goodwill impairment loss would be recorded. Another critical factor in the decision to write down goodwill appeared to be CEO tenure (i.e., a CEO who made the acquisition giving rise to the goodwill was less likely to record an impairment loss than a successor CEO).

Masters-Stout, Costigan, and Lovata (2008) tested a specific aspect of big bath accounting via goodwill impairments by examining the association between CEO tenure and these write offs. They speculated that "CEOs tend to manipulate impairment in the early years of their tenure since blame can be placed on [prior] management's acquisition decisions and expensing goodwill early can improve future earnings" (Masters-Stout et al., 2008, p. 1371). They examined goodwill impairments for the U.S. Fortune 500 companies in 2003-2005 (i.e., the first three years subsequent to SFAS 142's transition year). Their results indicated that the mean goodwill impairment for junior CEOs (i.e., those who had been in this position for three years or less) was significantly larger than the mean for the senior CEOs. The researchers also discovered that the amount of the goodwill impairments was inversely related to current-year income and that firms with negative current-year earnings were much more prone to write down goodwill than companies with positive earnings. Masters-Stout et al. (2008) suggested that this finding supports the notion that big bath accounting was occurring relative to goodwill impairments. However, they examined earnings for the impairment year only and admitted that it is possible that declining earnings could be an indication that an entity's goodwill is decreasing as well. They noted that future research is needed to explore this issue more closely.

Godfrey and Koh (2009) analyzed the relationship between recording a goodwill impairment and a firm's investment opportunity factor using 2003 and 2004 U.S. data. Investment opportunity represented a conglomerate of six different measures (e.g., mean annual growth rate of market value of assets, research and development expenditures to total assets, earnings-to-price ratio, etc.). The researchers found a strong negative association between a firm's investment opportunity and the amount of goodwill written off. That is, companies with low investment opportunity (i.e., poor economic outlook) wrote off more goodwill than firms with strong investment opportunity. Thus, Godfrey and Koh (2009) concluded that goodwill impairments under SFAS 142 were not reported opportunistically but rather were a signal by management of the economic condition of the company.

Jarva (2009) examined the association between goodwill impairments and expected future cash flows for U.S. companies during the years 2002-2005 and found that these write offs possessed significant predictive ability for in-firm cash flows one and two years ahead. Jarva (2009), therefore, concluded that goodwill impairments were more closely associated with economic factors than with opportunistic reporting. Lee and Yoon (2012) analyzed the predictive ability of earnings relative to future cash flows and discovered that it improved after SFAS 142's implementation. Thus, they surmised that goodwill impairments in the U.S. were not being reported opportunistically but instead conveyed relevant economic information.

The majority of studies testing for opportunistic behavior and big bath accounting relative to goodwill impairments have done so in the U.S., but some non-U.S. research exists in this area as well. For example, AbuGhazaleh et al. (2011) examined goodwill impairments in the U.K. in 2005 and 2006, which represents the initial years of IAS 36's application in that country. Even during this transition period, though, goodwill write offs in the U.K. were reported as operating expenses, rather than below-the-line items. The researchers' results were somewhat mixed in that they found evidence of opportunistic reporting (e.g., goodwill impairments appeared to be associated with big bath behavior and also with CEO changes). Yet, a strong association existed between effective governance mechanisms and goodwill impairments, which indicated that the write offs reflected management's private information about the company and its underlying economic performance.

Abuaddous, Hanefah, and Laili (2014) tested for opportunistic reporting and big bath behavior relative to goodwill impairments in Malaysia in 2012, which was the transition year for that country's adoption of IFRS (including the goodwill impairment standard). Their results were somewhat perplexing in that more evidence existed of big bath accounting associated with goodwill impairments in 2011 (i.e., the year prior to mandatory impairment testing) than in the transition year (i.e., 2012). Abuaddous et al. (2014) warned against generalizing their results outside of Malaysia, where goodwill is much less significant than in most other countries. They suggested that many Malaysian managers simply wrote off their firms' goodwill accounts in 2011 to avoid the arduous impairment test under IAS 36 (i.e., 25\% of the Malaysian companies with goodwill completely eliminated this asset in 2011). 
Lapointe-Antunes et al. (2008) looked for opportunistic recording of goodwill impairments in Canada in the transition year (2002) for Section 3062 of the Canadian Institute of Chartered Accountants' Handbook. The requirements of Section 3062 echoed those of SFAS 142 in the U.S., with one primary exception. For the transition year in the U.S., goodwill impairments were presented below-the-line in the income statement, while in Canada they bypassed income and were treated retroactively as adjustments to retained earnings. Lapointe-Antunes et al. (2008) found that the transitional goodwill impairments were recorded opportunistically by firms that needed to increase their return on assets (ROA) and return on equity (ROE) ratios to minimize deviations from industry norms. Since transitional impairment losses had no negative effect on income but lowered both assets and equity, their net effect was an increase in ROA and ROE, respectively. The researchers also discovered that firms changing CEOs in 2002 reported higher transitional impairment losses than companies not changing CEOs that year. As discussed previously, this represents a form of opportunistic reporting whereby the new CEO can blame prior management for their poor acquisition decisions while at the same time enhancing future profits.

In summary, virtually all the studies conducted during the transition year for the goodwill impairment standard found evidence that the impairments were opportunistically recorded (e.g., AbuGhazaleh et al., 2011; Beatty \& Weber, 2006; Jordan \& Clark, 2004; Lapointe-Antunes et al., 2008; Sevin \& Schroeder, 2005). In periods subsequent to the transition year, though, results have been mixed, with some studies indicating big bath behavior occurred relative to recording goodwill impairments (e.g., Jordan et al., 2007; Masters-Stout et al., 2008), while others concluded that goodwill impairments reflected relevant economic information about a company's financial performance (e.g., Godfrey \& Koh, 2009; Jarva, 2009; Lee \& Yoon, 2012). The post-transition studies have been conducted predominantly in the U.S.

The mixed findings in the post-transition years and the scarcity of studies outside the U.S. during this era indicate additional research is needed relative to the debate of whether goodwill impairments are more the result of opportunistic reporting or of management's desire to provide relevant economic information about their firm's performance. The current study examines this issue for a recent post-transition year (i.e., 2013) in Canada.

The only study testing for opportunistic reporting of goodwill impairments in Canada (i.e., Lapointe-Antunes et al., 2008) did so in the transition year for Section 3062 when the goodwill impairment loss affected retained earnings rather than income. Section 3062, which was similar to SFAS 142 in the U.S., represented the goodwill impairment standard in Canada from 2002-2010. However, in 2011 Canada adopted IFRS, and IAS 36 now guides the recording of goodwill impairments in this country. The goodwill impairment test under IAS 36 differs from that of the predecessor standard (i.e., Section 3062) in a few key ways (e.g., the definition of the reporting unit to which goodwill is allocated and, more importantly, the determination of whether an impairment loss exists as well as its amount).

For example, under Section 3062, the impairment test was a two-step process, with the first step involving a comparison between a reporting unit's fair value and its carrying value. If the unit's carrying value exceeded its fair value, a second step was needed to allocate the unit's fair value to each of its identifiable assets. Any fair value remaining after this allocation represented the fair value of the unit's goodwill. If the carrying value of the unit's goodwill exceeded the goodwill's fair value, this excess was recorded as an impairment loss with a commensurate reduction in goodwill. As noted in the introduction, under IAS 36 if the carrying value of the reporting unit exceeds its recoverable amount, any such excess is first recorded as a goodwill impairment and then as pro rata reductions of other assets once (if) goodwill is eliminated. The impairment tests under both Section 3062 and IAS 36 require significant managerial discretion, yet each standard could lead to a different decision about the need to record an impairment or to impairments of differing magnitudes if a write down is warranted.

Thus, no study has tested for big bath behavior relative to goodwill impairments in Canada under the current standard (i.e., IAS 36), which leads to the primary research question in this study. More specifically, under IAS 36 in Canada, do goodwill impairments seem to be recorded opportunistically so that big bath earnings management can be accomplished or do they appear to be the result of management's desire to provide relevant information about their firm's operating performance over time?

\section{Methodology and Data}

The methodology used in the current study to evaluate whether goodwill impairments appear to be recorded opportunistically in Canada in a post-transition year resembles the technique used in several of the studies conducted in the transition year (e.g., Jordan \& Clark, 2004, and Sevin \& Schroeder, 2005, in the U.S and Abuaddous et al., 2014, in Malaysia). In particular, opportunistic reporting reflective of big bath behavior would 
be indicated if firms recording goodwill impairments have earnings significantly below that of non-impairment companies in the year of impairment but not in the years immediately preceding the impairment year. The notion here is that the impairment loss was taken in the current period not because of declining performance over time but rather because the company would be punished relatively little for reducing its already low current-year earnings even further. However, if a firm writing down goodwill reports income significantly below that of non-impairment companies in the current year (i.e., year of impairment) and in the years immediately preceding the impairment year, evidence would suggest the impairment was not recorded opportunistically. Instead, the impairment was likely recorded because of the firm's declining performance over time and management's desire to share with financial statement users that the synergies that previously led to the entity's above average earnings potential (i.e., its goodwill) have diminished.

To test for opportunistic reporting of goodwill impairments in Canada, select financial data are collected for all Canadian companies with goodwill that are contained in the 2013 Fundamentals Annual COMPUSTAT file. The year 2013 is chosen as the sample period because at the time of this study it represents the most recent year for which data are available for the post-transition period of IAS 36. 2011 was the first year Canada used IFRS and IAS 36; thus, 2013 is not a transition year for the goodwill impairment standard. Plus, management should have been comfortable with the intricacies of the standard's impairment test by this time (i.e., 2013 should have been a normal year for applying IAS 36 in Canada). The companies reporting goodwill at the beginning of their 2013 financial reporting year are segregated into two groups, those recording goodwill impairment losses in 2013 and those not doing so. For both groups of firms, data are also collected for the two prior years (i.e., 2012 and 2011) so that analyses and comparisons can be made of the operating performance of the companies in the two groups for the year of impairment (2013) and the two years immediately preceding the impairment year.

One measure of operating performance examined in prior studies testing for opportunistic behavior relative to recording goodwill impairments is whether the firms reported negative or positive income (e.g., Abuaddous et al., 2014; Jordan \& Clark, 2004; Masters-Stout et al., 2008; Sevin \& Schroeder, 2005). For example, if a company experiences negative income in the year goodwill is written down but positive income in the years immediately prior to the impairment year, there exists a good chance the impairment loss was recorded in the current year to take advantage of the already depressed earnings that year (i.e., big bath behavior).

Classifying income as negative versus positive represents a dichotomous measure of operating performance. ROA has frequently been used to capture the relative degree or magnitude of operating performance in prior goodwill impairment studies (e.g., Abuaddous et al., 2014; Frances, Hanna, \& Vincent, 1996; Jordan \& Clark, 2004; Lapointe-Antunes et al., 2008; Sevin \& Schroeder, 2005). The poorer a firm's past performance (i.e., ROA), the greater the likelihood that its goodwill has diminished in value and should be written down via an impairment loss (AbuGhazaleh et al., 2011, p. 180).

Chi-square tests are used for comparing the rates at which companies in the impairment and non-impairment groups reported negative versus positive income for each of the years under study. Medians, rather than means, are used as the summary statistic for comparing the ROAs between the impairment and non-impairment groups. Medians are used because a few outlying observations can frequently result in the mean being an unrepresentative measure of central tendency, especially when the sample size is relatively small (i.e., only 68 Canadian companies in our sample wrote down goodwill in 2013). The median value for a group is largely unaffected by these outlying observations (Mason, 1978, p. 54; Spizman, 2013, p. 79). A Mood's median test is used to compare the median ROAs between the impairment and non-impairment groups each year. The null hypothesis in this nonparametric test is that if there is no difference between the two groups, then the proportion of values below and above the grand median for both groups should be approximately equal. A Chi-square statistic is used for determining the statistical significance of the difference in the proportions for the two groups (see Chen, 2014, for more discussion of Mood's median test).

\section{Results}

Of the 1746 Canadian firms in COMPUSTAT's 2013 Fundamentals Annual file, 413 (23.65\%) had goodwill at the beginning of the year. Of the 413 companies reporting goodwill in 2013, 68 (16.46\%) recorded an impairment loss on this asset during the year while $345(83.54 \%)$ did not. Table 1 provides descriptive statistics for 2013 for the full sample of 413 firms reporting goodwill in 2013 and for the impairment and non-impairment groups as well. 
Table 1. Descriptive statistics for 2013

\begin{tabular}{lccccc}
\hline & $\begin{array}{c}\text { Full sample } \\
(\mathrm{n}=413)\end{array}$ & $\begin{array}{c}\text { Impairment group } \\
(\mathrm{n}=68)\end{array}$ & $\begin{array}{c}\text { Non-impair. group } \\
(\mathrm{n}=345)\end{array}$ & Chi-square & p-level \\
\hline Median goodwill at beg. of year (millions) & $\$ 36.00$ & $\$ 60.16$ & $\$ 31.55$ & 2.33 & .127 \\
Median goodwill/total assets at beg. of year & $7.77 \%$ & $13.55 \%$ & $7.19 \%$ & 6.93 & $.009^{*}$ \\
Median total assets (millions) & $\$ 545$ & $\$ 513$ & $\$ 551$ & .004 & .948 \\
\hline
\end{tabular}

Note. Chi-square statistic and p-level are for a Mood's median test comparing the medians for the impairment and non-impairment groups. * is significant at .01 level.

Table 1 shows that the median amount of goodwill as a percentage of total assets for the impairment group of $13.55 \%$ is significantly larger than the median amount for the non-impairment group of $7.19 \%$ (i.e., p-level of .009). This result is intuitive because the greater the portion of a firm's assets that are comprised of goodwill, the more likely that firm will experience an impairment of goodwill (i.e., relative to a company for which goodwill makes up only a small fraction of its assets). There appears to be very little size differential between firms in the two groups as median total assets for the impairment companies of $\$ 513$ million fell very close to the median total assets for the non-impairment firms of $\$ 551$ million (i.e., p-level of .948).

For the 68 companies writing down goodwill in 2013, the median amount of the impairment represented 24.37\% and $1.85 \%$ of the beginning of the year balance of goodwill and total assets, respectively. The median amount of the impairment to the absolute value of income from continuing operations was $26.29 \%$. Eilifsen and Messier (2015) examined the materiality guidance of eight of the largest public accounting firms and found that for determining the overall materiality of an item, the majority of the firms expect or require the use of $5 \%$ of income before taxes. Clearly, the goodwill impairments recorded by the Canadian companies in 2013 would be considered material (i.e., median impairment to income of 26.29\%). The question is whether these significant hits to income were recorded in an opportunistic manner characteristic of big bath behavior.

Panel A of Table 2 shows a two-by-two contingency table providing the number of firms with positive income and the number with negative income for 2013 for the impairment and non-impairment groups. Notice that the majority $(73.5 \%)$ of the companies writing down goodwill reported a net loss for the year while only $23.8 \%$ of the non-impairment firms incurred negative income in 2013. A Chi-square test reveals that these proportions differ significantly between the impairment and non-impairment groups (i.e., p-level of .000).

Table 2. Firms with positive or negative income for impairment and non-impairment groups

\begin{tabular}{|c|c|c|c|c|c|}
\hline & Impairment group & Non-impair. group & Total & Chi-square & p-level \\
\hline \multicolumn{6}{|c|}{ Panel A (Impairment year i.e.,2013): } \\
\hline Positive income & $18(26.5 \%)$ & $263(76.2 \%)$ & 281 & & \\
\hline Negative income & $50(73.5 \%)$ & $82(23.8 \%)$ & 132 & & \\
\hline Total & $68(100 \%)$ & $345(100 \%)$ & 413 & 68.88 & $.000 *$ \\
\hline \multicolumn{6}{|c|}{ Panel B (Year before impairment i.e., 2012): } \\
\hline Positive income & $39(58.2 \%)$ & $246(72.8 \%)$ & 285 & & \\
\hline Negative income & $28(41.8 \%)$ & $92(27.2 \%)$ & 120 & & \\
\hline Total & $67(100 \%)$ & $338(100 \%)$ & 405 & 5.7 & $.017 * *$ \\
\hline \multicolumn{6}{|c|}{ Panel C (Two years before impairment i.e., 2011): } \\
\hline Positive income & $39(60.0 \%)$ & $237(79.3 \%)$ & 276 & & \\
\hline Negative income & $26(40.0 \%)$ & $62(20.7 \%)$ & 88 & & \\
\hline Total & $65(100 \%)$ & $299(100 \%)$ & 364 & 10.81 & $.001 *$ \\
\hline
\end{tabular}

Note. The total numbers of firms in 2012 and 2011 are less than the total number in 2013 because data for some of the firms in the 2013 COMPUSTAT file were unavailable in the earlier COMPUSTAT files. * and ** are significant at .01 and .05 levels, respectively.

Initially, the 2013 results in Panel A might suggest the firms writing down goodwill did so opportunistically because of the depressed earnings in the current year (i.e., with the notion that the impairment loss would do little additional harm). However, as Lhaopadchan (2010) notes, the decision to write down goodwill could also be a signal from management to investors about firm performance. If the impairment group has a significantly larger percentage of entities with negative earnings than the non-impairment group in the years leading up to the 
impairment year (i.e., years 2012 and 2011), evidence would support the argument that the impairment results from management signaling investors and others that the firm's excess earnings potential that originally gave rise to the goodwill no longer exists or does so in a reduced capacity.

For the 2013 impairment and non-impairment groups, Panels B and C of Table 2 show the number of companies with negative earnings and the number with positive income in 2012 and 2011, respectively. Even though Panels $\mathrm{B}$ and $\mathrm{C}$ show that the majority of the impairment group reported positive income in both years, the impairment group's operating performance was significantly below that of the non-impairment group for these years. For example, Panel B indicates that $41.8 \%$ of the firms that recorded impairments in 2013 experienced a net loss in 2012, while only $27.2 \%$ of the 2013 non-impairment firms had negative earnings in 2012. The Chi-square test reveals that these proportions differ significantly (i.e., p-level of .017). Panel C reveals a similar finding for 2011 (i.e., two years prior to the impairment year). In particular, in $201140 \%$ of the firms writing down goodwill in 2013 incurred a net loss, while only $20.7 \%$ of the 2013 non-impairment group had negative income in 2011; these rates differ significantly (i.e., p-level of .001). Thus, Table 2 indicates that, compared to the firms not recording impairment losses in 2013, the 2013 impairment group significantly underperformed not only in the year of impairment, but also in the two prior years.

While Table 2 provides a binary measure of performance (i.e., positive versus negative income) over time, Table 3 shows an analysis of ROA, which represents a relative measure of profitability. Median ROAs are reported for the overall sample of firms that had goodwill in 2013 and for the subsamples of firms that wrote down goodwill that year as well as the ones that did not. Median ROAs are also provided for these same groupings for each of the two years immediately preceding the impairment year (i.e., 2012 and 2011). Notice that the median ROA for the impairment group in 2013 of $-5.26 \%$ fell significantly below the median ROA for the non-impairment group that year of $2.76 \%$ (i.e., p-level of .000). However, results from the two prior years are more important for ascertaining whether the impairments in 2013 resulted from big bath accounting or instead from management signaling relevant information about the firm's performance over time.

Table 3. Median ROAs for impairment year and two prior years

\begin{tabular}{lccccc}
\hline & \multicolumn{3}{c}{ Median ROA } \\
\hline & Full sample & Impairment group & Non-impair. group & Chi-square & p-level \\
\hline Impairment year (2013) & $1.97 \%$ & $-5.26 \%$ & $2.76 \%$ & 37.52 & $.000^{*}$ \\
Year before impairment (2012) & $2.72 \%$ & $1.31 \%$ & $3.02 \%$ & 5.27 & $.022^{* *}$ \\
Two years before impairment (2011) & $3.71 \%$ & $1.89 \%$ & $3.96 \%$ & 3.16 & $.075^{* * *}$ \\
\hline
\end{tabular}

Note. Chi-square statistic and p-level are for a Mood's median test comparing the medians for the impairment and non-impairment groups each year. *,**, and *** are significant at $.01, .05$, and .10 levels, respectively.

Table 3 shows that in 2012, the group of firms writing down goodwill in 2013 generated a median ROA of only $1.31 \%$, which was less than half the 2012 median ROA of $3.02 \%$ for the companies that did not record goodwill impairments in 2013; the 2012 median ROAs differed between the two groups at a statistically significant level (i.e., p-level of .022). A similar phenomenon occurred in 2011 (i.e., two years prior to the impairment year). More specifically, the 2011 median ROA (1.89\%) for the group that wrote down goodwill in 2013 fell significantly below the 2011 median ROA (3.96\%) for the 2013 non-impairment group (i.e., p-level of .075).

One final test for the presence of big bath behavior involved examining operating performance in the year after the impairment loss was recorded (i.e., 2014). Relative to firms not recording a goodwill impairment in 2013, companies reporting such an impairment due to poor economic performance would be expected to experience depressed earnings not just in the year of impairment (i.e., 2013) and the years leading up to that year (i.e, 2012 and 2011) but also in the year following the impairment (i.e., 2014). However, a company taking an impairment loss in 2013 primarily because of depressed earnings that year (i.e., big bath accounting) would not be expected to exhibit substandard earnings the next year.

In 2014, 53.1\% of the 2013 impairment firms reported negative earnings while only $24.4 \%$ of the 2013 non-impairment firms experienced a net loss in 2014; these proportions differ at a significant level (i.e., chi-square statistic of 16.97 with a p-level of .000). For the 2013 impairment group, their 2014 median ROA of $-.74 \%$ fell significantly below the 2014 median ROA (i.e., 2.23\%) for the 2013 non-impairment group (i.e., p-level of .003 for a Mood's median test). Thus, compared to the companies that did not write down goodwill in 2013, those that did displayed substandard operating performance not only in the year of impairment but also in 
multiple periods surrounding the impairment year.

Without knowing management's true intentions with respect to recording goodwill impairments, the presence or absence of big bath behavior relative to these write downs cannot be proven definitively. The results of Tables 2 and 3 admittedly show the majority of the impairment group reported positive income and ROA for the two years prior to impairment. Even so, these results for the impairment group are clearly inferior to the results for the non-impairment group for the same period. Therefore, the findings in this study provide substantial anecdotal evidence that the goodwill impairments taken in 2013 were not the result of opportunistic reporting. Instead, the findings suggest the impairments recorded in 2013 were justified based on multiple years of substandard operating performance (i.e., relative to the performance levels of the firms not writing down goodwill in 2013). Through these goodwill impairments, it seems managers were attempting to provide relevant economic information about their firms to financial statement users.

\section{Summary, Conclusion, and Limitations}

In the transition year for the goodwill impairment standard, these write downs received favorable reporting treatment. For example, in the U.S. they were presented as below-the-line expenses in the income statement, and in Canada they bypassed income and were recorded instead as reductions in retained earnings. Research showed that management opportunistically recorded goodwill impairments in the transition year (2002) in both the U.S. and Canada (e.g., see Beatty \& Weber, 2006; Jordan \& Clark, 2004; Lapointe-Antunes et al., 2008; Sevin \& Schroeder, 2005). Subsequent to the transition year, goodwill impairments in all countries have been reported in a more punitive manner (i.e., as above-the-line expenses in the earnings statement). This more punitive reporting might provide a disincentive to management recording impairments to goodwill opportunistically.

Research in the U.S. in the post-transition period provides mixed results with some studies suggesting managers practiced big bath behavior when recording goodwill impairments (e.g., Jordan et al., 2007; Masters-Stout et al., 2008), while other researchers found evidence indicating managers did not write down goodwill opportunistically but rather did so to present relevant economic information about the financial performance of their firms (e.g., see Godfrey \& Koh, 2009; Jarva, 2009; Lee \& Yoon, 2012). No post-transition era studies have been conducted in Canada to ascertain whether goodwill impairments in this country result from opportunistic reporting reflective of big bath behavior or alternatively from management's desire to provide economic information about their firm's deteriorating performance over time. The current study fills this void in the literature.

All Canadian companies in the COMPUSTAT Fundamentals Annual file with goodwill existing at the beginning of 2013 were segregated between those that recorded goodwill impairment losses in 2013 and those that did not. Relative to the non-impairment group, the firms writing down goodwill experienced significantly lower operating performance not only in the year of impairment, but also in the two prior years as well as the year after the impairment was recorded. This suggests managers of the firms recording impairment losses did not take these write downs simply because earnings were depressed in the current year (i.e., big bath behavior) but did so because of multiple years of subpar operating performance, which indicates that the above average earnings potential that had originally given rise to the goodwill no longer existed. Thus, it seems Canadian managers wrote down goodwill in an effort to convey relevant information to financial statement users. The extent to which goodwill write downs being reported as an above-the-line item on the income statement affected the impairment decision cannot be determined. Yet, this change in reporting could help explain the difference in the findings of the current research and the studies that focused on the transition years (i.e., when the opportunistic recording of goodwill impairments may have been fueled by the favorable reporting treatment they received).

As with any empirically based project, time and data availability constraints limit the generalizability of this study's findings somewhat. For example, we tested for opportunistic reporting related to goodwill impairments recorded in 2013 because this represented the most recent post-IAS 36 year in Canada for which data were available for the surrounding periods. Future research could examine later years to ascertain whether the results found here remain consistent over time. In addition, because of the relatively small number of Canadian firms that wrote down goodwill in 2013 (i.e., 68) we did not perform industry analyses in the current study even though some prior research (e.g., Baik, Kwak, \& Lee, 2011) suggests the propensity to manage earnings may be higher in specific industries (e.g., those with greater product competition). Finally, as noted earlier, research indicates that new CEOs may be more prone than senior CEOs to engage in big bath behavior when recording asset impairments (e.g., Beatty \& Weber, 2006; Francis et al., 1996; Masters-Stout et al., 2008). Our results could have been different if we had analyzed data from specific industries rather than a cross-industry sample or had segregated our sample between senior and junior CEOs. Future research could test these issues. 


\section{References}

Abuaddous, M., Hanefah, M., \& Laili, N. (2014). Accounting standards, goodwill impairment and earnings management in Malaysia. International Journal of Economics and Finance, 6(12), 201-211. http://dx.doi.org/10.5539/ijef.v6n12p201

AbuGhazaleh, N., Al-Hares, O., \& Roberts, C. (2011). Accounting discretion in goodwill impairments: UK evidence. Journal of International Financial Management \& Accounting, 22(3), 165-204. http://dx.doi.org/10.1111/j.1467-646X.2011.01049.x

Baik, Y., Kwak, B., \& Lee, S. (2011). Deregulation and earnings management: The case of the U.S. airline industry. Journal of Accounting and Public Policy, 30, 589-606. http://dx.doi.org/10.1016/j.jaccpubpol.2011.08.006

Beatty, A., \& Weber, J. (2006). Accounting discretion in fair value estimates: An examination of SFAS 142 goodwill impairments. Journal of Accounting Research, 44, 257-288. http://dx.doi.org/10.1111/j.1475-679X.2006.00200.x

Bens, D., \& Heltzer, W. (2004). The information content and timeliness of fair value accounting: An examination of goodwill write-offs before, during, and after the implementation of SFAS 142. Working paper. University of Chicago. http://dx.doi.org/10.2139/ssrn.590345

Chen, Z. (2014). Extension of Mood's median test for survival data. Statistical Probability Letters, 95, 77-84. http://dx.doi.org/10.1016/j.spl.2014.08.006

Eilifsen, A., \& Messier, W. (2015). Materiality guidance of the major public accounting firms. Auditing: A Journal of Practice \& Theory, 34(2), 3-26. http://dx.doi.org/10.2308/ajpt-50882

Francis, J., Hanna, D., \& Vincent, L. (1996). Causes and effects of discretionary asset write-offs. Journal of Accounting Research, 34, 117-134. http://dx.doi.org/10.2307/2491429

Godfrey, J. \& Koh, P. (2009). Goodwill impairment as a reflection of investment opportunities. Accounting and Finance, 49(1), 117-140. http://dx.doi.org/10.1111/j.1467-629X.2008.00272.x

Jarva, H. (2009). Do firms manage fair value estimates? An examination of SFAS 142 goodwill impairments. Journal of Business Finance and Accounting, 36, 1059-1086. http://dx.doi.org/10.1111/j.1468-5957.2009.02169.x

Jordan, C., \& Clark, S. (2004). Big bath earnings management: The case of goodwill impairment under SFAS No. 142. Journal of Applied Business Research, 20(2), 63-69.

Jordan, C., Clark, S., \& Vann, C. (2007). Using goodwill impairment to effect earnings management during SFAS No. 142's year of adoption and later. Journal of Business \& Economics Research, 5(1), 23-30.

Lapointe-Antunes, P., Cormier, D., \& Magnan, M. (2008). Equity recognition of mandatory accounting changes: The case of transitional goodwill impairment losses. Canadian Journal of Administrative Sciences, 25(1), 37-54. http://dx.doi.org/10.1002/cjas.41

Lee, C., \& Yoon, S. (2012). The effects of goodwill accounting informativeness of earnings: Evidence from earnings persistence and earnings' ability to predict future cash flows. Journal of Accounting and Finance, 12(3), 124-147.

Lhaopadchan, S. (2010). Fair value accounting and intangible assets: Goodwill impairment and managerial choice. Journal of Financial Regulation and Compliance, 18(2), 120-130. http://dx.doi.org/10.1108/13581981011033989

Mason, R. (1978). Statistical techniques in business and economics (4th ed.). Homewood, IL: Richard D. Irwin, Inc.

Massoud, M., \& Raiborn, C. (2003). Accounting for goodwill: Are we better off? Review of Business, 24(2), 26-32.

Masters-Stout, B., Costigan, M., \& Lovata, L. (2008). Goodwill impairments and chief executive officer tenure. Critical Perspectives in Accounting, 19, 1370-1383. http://dx.doi.org/10.1016/j.cpa.2007.04.002

Sevin, S., \& Schroeder, R. (2005). Earnings management: Evidence from SFAS No. 142 reporting. Managerial Auditing Journal, 20, 47-54. http://dx.doi.org/10.1108/02686900510570696

Spizman, L. (2013). Developing statistical based earnings estimates: Median versus mean earnings. Journal of Legal Economics, 19(2), 77-82. 
Walsh, P., Craig, R., \& Clarke, F. (1991). Big bath accounting using extraordinary items adjustments: Australian empirical evidence. Journal of Business Finance and Accounting, 18, 173-189. http://dx.doi.org/10.1111/j.1468-5957.1991.tb00587.x

\section{Copyrights}

Copyright for this article is retained by the author(s), with first publication rights granted to the journal.

This is an open-access article distributed under the terms and conditions of the Creative Commons Attribution license (http://creativecommons.org/licenses/by/3.0/). 